\title{
PROSES PEMBUATAN TEMPAT SAMPAH
}

\author{
RAHMIATI \\ 9173770410244 \\ lavenderhime11@gmail.com
}

1. Bentuk Kegiatan

Pengasahan bambu sebagai bahan pembuatan tempat sampah

2. Lokasi

Rumah anggota PKK, Dusun Pa'borongan Desa Bontocini Kecamatan Rumbia

3. Hari/Tanggal dan Waktu Kamis, 01-10-2020, jam 11:27

4. Peserta yang Dilibatkan

- Mahasiswa KKLP

- Karang taruna Desa Bontocini

5. Alasan Diadakannya

Sebagai salah satu proses pembuatan tempat sampah

6. Tujuan dan Manfaat

9. Referensi Wajib

- HERIANTO, H., \& Amir, A. S. (2020, September 10). Pedoman Pelaksanaan Kuliah Kerja Lapangan Plus (KKLP) Mahasiswa STIE dan STKIP YAPTI Jeneponto. https://doi.org/10.31219/osf.io/7dvpk
Tujuan dan manfaat yaitu untuk mempermudah pembuatan tempat sampah dan sebagai wahadah sampah.

\section{Produk Kegiatan (Jika Ada)}

Bambu

8. Deskripsi Kegiatan

Pada jam 8 pagi kami semua pergi mengambil bambu di kebun masyarakat dan setelah itu di potong kecil dan di asah agar memudahkan pembentukan tempat sampah. 